\title{
Processed Canola Meal Effects on the Traits of Egg, Fertility, Cecal Microbial Population and Carcass of Broiler Breeder Hens
}

Original Article

-Author(s)

Dolatifard A' (iD https://orcid.org/0000-0002-9788-1080 Jafari MA' (D) https://orcid.org/0000-0001-7608-6371

Department of Animal Science, Qaemshah Branch, Islamic Azad University, Qaemshahr, Iran.

\section{-Mail Address}

Corresponding author e-mail address Mohammad Ali Jafari

Qaemshahr Branch, Islamic Azad University - Tabarsi Road - Qaemshahr - Mazandaran -

Postal code: 4519097256 - Iran.

Phone: +0098 9126501144

Email: MohammadAli3Jafari@yahoo.com

\section{aKeywords}

Caecum, Fermentation, Fertility, Processing.

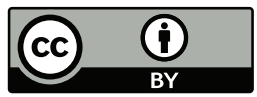

Submitted: 24/April/2020

Approved: 15/September/2020

\section{ABSTRACT}

The aim of the current research was to study the effect of canola meal processing methods on the traits of egg, fertility, cecal microbial population, and the carcass of broiler breeder hens. Canola meal was processed by fermentation and enzymatic hydrolysis methods, then was fed to the hens. Four hundred and fifty broiler breeder hens of Ross strain weighing $3300 \pm 150 \mathrm{~g}$ (40 weeks) were used for 12 weeks. A completely randomized design was used with 6 treatments (unprocessed, processed by Lactobacillus Plantarum, Bacillus Subtilis, Aspergillus Oryzae, Neurospora Sitophila, and Alcalase enzyme) and 5 replications. Fifteen hens were included in each pen. The data collected were analyzed using the LSmeans procedure of SAS software. The treatment effect was significant on the fertility hatchability $(p<0.05)$. The highest fertility hatchability was observed in the processing method by Neurospora Sitophila fungi (85\%). Experimental treatments had significant effects on the germs and $\mathrm{pH}$ of the caecum $(p<0.05)$. The use of processing methods reduced the population of salmonella and coliforms and increased the population of lactobacillus in the caecum. Most of the population of salmonella, lactobacillus, and coliforms of the caecum was observed in the treatments of unprocessed, Bacillus Subtilis bacteria, and unprocessed, respectively. The effect of the experimental treatment had significant effect on abdominal fat $(p<0.05)$. Processing methods of canola caused the reduction of abdominal fat. The highest decrease in abdominal fat was observed in the treatment that processed Aspergillus Oryzae fungi (1.89\%). Processing of canola meal improved its digestibility and reduced its anti-nutritional factors.

\section{INTRODUCTION}

Canola is scientifically named Brassica Napus from the family Brassicaceae Cruciferae. Canola meal is the most important plant protein product after soybean meal. In poultry rations, soybean can be replaced by canola. Canola is derived from the rapeseed breeding by reducing the glucosinolate amount (Recoules et al., 2019). The amount of erucic acid in canola oil is less than $2 \%$ and the amount of glucosinolate in its meal is less than $30 \mu \mathrm{mol} / \mathrm{g}$ (Zeb, 1998). The major anti-nutrient components of canola are phytate, glucosinolate, and tannin. These compounds reduced the ration palatability. Glucosinolates are not normally toxic. But secondary products from their decomposition can have adverse effects on bird performance (Tripathi \& Mishra, 2007). High consumption of glucosinolates in broiler chickens reduces feed intake, decreases growth rate, hyperthyroidism, decreases thyroid hormone levels, enlarges liver, kidney and thyroid gland, and also changes liver activity, and increases mortality (McNeill et al., 2004; Kermanshahi \& Abbasi Pour, 2006). 
Nowadays, the production of new feeds has been considered. These feeds were made with the fermentation technology by fungal species (such as Rhizopus Oligosporus, Aspergillus Oryza, Neurospora Cytophila and Aspergillus Niger) and bacterial species (such as Enterococcus Faecium and Bacillus Subtilis) (Ravindra, 2000; Singhania et al., 2009). Fermentation technology eliminates anti-nutritional compounds and improves the structure and taste of the feed. Fermentation technology is better at processing feed than chemical methods. The use of microbial fermentation methods to produce high-quality protein and free from anti-nutritional compounds has been considered (Khalil, 2006).

In the process of hydrolyzing proteins by chemical methods (acid and alkaline solutions), enzymatic and fermentative, peptides are produced with beneficial feed properties such as antioxidant properties, immune system stimuli, antimicrobial, blood pressure modulation, anti-cancer, and anti-obesity production. (Brij et al., 2014). In the enzymatic hydrolysis of proteins, the hydrolysis process is completely controlled, resulting in the production of peptides with biologically active properties (Pasupuleti \& Demain, 2010). The enzymatic hydrolysis of plant proteins, such as canola meal, produced peptides that are used as natural ingredients in the production of useful feeds and can be used in animal nutrition because of their high absorption capacity from the small intestine (Brij et al., 2014).

The purpose of the present research was to study the effect of canola meal processing by bacteria, fungi, and enzyme on the traits of egg, fertility, cecal microbial population and carcass of broiler breeder hens.

\section{MATERIALS AND METHODS}

\section{Canola meal and processing methods}

The canola meal was processed by fermentation and enzymatic hydrolysis. Fermentation processing was done by 2 bacteria strains named Lactobacillus Plantarum and Bacillus Subtilis, and 2 fungi strains named Aspergillus Oryzae and Neurospora Sitophila. Enzymatic hydrolysis was done by the Alcalase enzyme. Then, the canola meal processed was fed to the hens.

\section{Hens and experimental treatments}

In this study, four hundred and fifty broiler breeder hens of Ross strain weighing $3300 \pm 150 \mathrm{~g}$ (40 weeks) were used for 12 weeks. A completely randomized design was used with 6 treatments and 5 replications.
Thirty pens were designed and prepared to study the effect of treatments. Fifteen broiler breeder hens were included in each pen. Treatments included: 1) unprocessed canola meal, 2) canola meal processed by Lactobacillus Plantarum, 3) canola meal processed by Bacillus Subtilis, 4) canola meal processed by Aspergillus Oryzae, 5) canola meal processed by Neurospora Sitophila, and 6) canola meal processed by Alcalase enzyme.

\section{Studied traits}

\section{Egg and fertility traits}

Eggs were collected 3 times per day. The egg weight and egg production were measured. The egg storage room had good conditions. Its temperature and relative humidities were $15-16{ }^{\circ} \mathrm{C}$ and $70 \%$, respectively. The eggs were weighed before the incubation. The eggs were incubated. After incubation, healthy and salable chickens and unhatched eggs were recorded. Total hatchability was calculated through the number of healthy hatched chickens divided by egg number multiples 100 . The fertility rate and fertility hatchability (the number of healthy hatched chickens divided by fertile eggs number multiples 100) were calculated.

\section{Total population of bacteria, Salmonella and Lactobacillus}

At the end of the experiment, after the slaughter of the hens, the contents of the caecum were drained with a syringe $(3 \mathrm{ml})$ and the syringe was kept in the refrigerator. Samples were transferred to the laboratory of Islamic Azad University, Qaemshahr Branch. MacConkey medium was used for Salmonella count and MRS agar for lactobacillus count. Salmonella was cultured in aerobic conditions and lactobacillus under anaerobic conditions. To prepare the sample, one gram of feces with $9 \mathrm{ml}$ of physiological serum solution was homogenized by Vertex (tube shaker). Then, one $\mathrm{ml}$ of the sample was mixed with $9 \mathrm{ml}$ of physiological serum and the diluted solution was obtained. Dilution with physiological serum continued until one-eighth. Samples were cultured in MRS agar and McConkey medium. The culture media were incubated for $2 \mathrm{~h}$ at $4{ }^{\circ} \mathrm{C}$. Then, the colonies were counted using a colony counting machine.

\section{Carcass traits}

At the end of the experiment, two hens were randomly selected from each pen and slaughtered after 12 hours of starvation. After slaughter, live weight, chest, thighs, wings, back and neck muscles, liver, spleen and pancreas were measured. 


\section{Experimental ration formulation}

The ration was formulated based on the nutritional requirements for the broiler breeder hens of Ross 308 (weeks 40 onwards) by corn, and soybean meal (Table 1).

Table 1 - Feed ingredients and chemical compositions of the ration used.

\begin{tabular}{lc}
\hline Ingredient & Amount in the ration (\%) \\
\hline Corn & 56.8 \\
Soybean meal (43\% CP) & 24.7 \\
Wheat bran & 6 \\
Soybean oil & 1.2 \\
Di-calcium phosphate & 1.5 \\
Oyster powder & 8 \\
Salt & 0.3 \\
Mineral supplement & 0.25 \\
Vitamin supplement & 0.25 \\
DL-methionine & 1 \\
\hline Chemical composition & \\
\hline Metabolizable energy (Kilocalories per kilogram) & 2740 \\
Crude protein (\%) & 15.50 \\
Methionine + Cysteine (\%) & 0.62 \\
Lysine (\%) & 0.77 \\
Calcium (\%) & 3.30 \\
Available Phosphorus (\%) & 0.38 \\
Sodium (\%) & 0.18 \\
\hline
\end{tabular}

Mineral supplement provides the following items: $50 \mathrm{mg}$ of manganese, $50 \mathrm{mg}$ of iron, $24 \mathrm{mg}$ of Zinc, $10 \mathrm{mg}$ of copper, $2 \mathrm{mg}$ of iodine, $200 \mu \mathrm{g}$ of selenium, $500 \mu \mathrm{g}$ of cobalt. Vitamin supplement provides the following items: 12000 international units (IU) of vitamin A, 3000 IU of vitamin D3, 100 IU of Vitamin E, $5 \mathrm{mg}$ of vitamin K3, 3 mg of vitamin $B 1,12 \mathrm{mg}$ of vitamin $B 2,55 \mathrm{mg}$ of vitamin $B 3,15 \mathrm{mg}$ of vitamin $B 5,4 \mathrm{mg}$ of pyridoxine, $2 \mathrm{mg}$ of vitamin B9, $40 \mu \mathrm{g}$ of vitamin B12, 1,000 mg of vitamin choline and $250 \mu \mathrm{g}$ of vitamin biotin

\section{Statistical analysis}

The data collected from the present study were analyzed using the LSmeans procedure of SAS statistical software (9.1). The statistical model used was as follows:

$$
\mathrm{y}_{\mathrm{ijk}}=\mu+\mathrm{A}_{\mathrm{i}}+\mathrm{e}_{\mathrm{ijk}}
$$

where $y_{i j k}$ is the value of each observation; $\mu$ is the effect of the mean; $A_{i}$ is the effect of the treatment and $\mathrm{e}_{\mathrm{ijk}}$ is the residual effect.

\section{RESULTS}

\section{Eggs and fertility traits}

Effects of canola meal process methods on Hen-day egg production, Egg weight, and Egg mass production are presented in Table 2. No significant effect was observed ( $p>0.05)$. As shown in Table 3, the effect of the treatments was significant on fertility hatchability $(p<0.05)$. The highest fertility hatchability was observed in the processing method with Neurospora Sitophila fungi $(85 \%)$.
Table 2 - Effect of treatments on egg traits of Ross broiler breeder hens.

\begin{tabular}{lccc}
\hline Treatments & $\begin{array}{c}\text { Hen-day egg } \\
\text { production (\%) }\end{array}$ & $\begin{array}{c}\text { Egg } \\
\text { weight(g) }\end{array}$ & $\begin{array}{c}\text { Egg mass } \\
\text { production } \\
\text { (g/hen/day) }\end{array}$ \\
\hline $\begin{array}{l}\text { Unprocessed } \\
\begin{array}{l}\text { Processed by } \\
\text { Lactobacillus Plantarum } \\
\text { (Bacteria) }\end{array}\end{array}$ & 61.86 & 52.23 & 34.12 \\
$\begin{array}{l}\text { Processed by Bacillus } \\
\text { Subtilis (Bacteria) }\end{array}$ & 62.57 & 52.90 & 34.98 \\
$\begin{array}{l}\text { Processed by Aspergillus } \\
\text { Oryzae (Fungi) }\end{array}$ & 61.97 & 52.84 & 35.13 \\
$\begin{array}{l}\text { Processed by } \\
\begin{array}{l}\text { Neurospora Sitophila } \\
\text { (Fungi) }\end{array}\end{array}$ & 62.13 & 53.10 & 34.84 \\
$\begin{array}{l}\text { Processed by Alcalase } \\
\text { enzyme }\end{array}$ & 62.30 & 52.92 & 34.69 \\
$\begin{array}{l}\text { SEM } \\
\text { p value }\end{array}$ & 1.29 & 1.63 & 1.01 \\
\hline
\end{tabular}

SEM: Standard error of means. Means with different letters are significant $(p<0.05)$.

Table 3 - Effect of treatments on fertility traits (\%) of Ross broiler breeder hens.

\begin{tabular}{|c|c|c|c|}
\hline Treatments & $\begin{array}{l}\text { Fertility } \\
\text { rate }\end{array}$ & $\begin{array}{c}\text { Fertility } \\
\text { hatchability }\end{array}$ & $\begin{array}{c}\text { Total } \\
\text { hatchability }\end{array}$ \\
\hline Unprocessed & 87 & $79^{a}$ & 70 \\
\hline $\begin{array}{l}\text { Processed by } \\
\text { Lactobacillus Plantarum } \\
\text { (Bacteria) }\end{array}$ & 89 & $83^{b}$ & 73 \\
\hline $\begin{array}{l}\text { Processed by Bacillus } \\
\text { Subtilis (Bacteria) }\end{array}$ & 88 & $83^{b}$ & 72 \\
\hline $\begin{array}{l}\text { Processed by } \\
\text { Aspergillus Oryzae } \\
\text { (Fungi) }\end{array}$ & 90 & $84^{b}$ & 73 \\
\hline $\begin{array}{l}\text { Processed by } \\
\text { Neurospora Sitophila } \\
\text { (Fungi) }\end{array}$ & 90 & $85^{b}$ & 72 \\
\hline $\begin{array}{l}\text { Processed by Alcalase } \\
\text { enzyme }\end{array}$ & 90 & $84^{b}$ & 72 \\
\hline SEM & 0.52 & 0.61 & 0.48 \\
\hline$p$ value & 0.12 & 0.00 & 0.10 \\
\hline
\end{tabular}

SEM: Standard error of means. Means with different letters are significant $(p<0.05)$.

\section{Caecum germs and pH}

Experimental treatments had significant effects on germs and $\mathrm{pH}$ of the caecum $(p<0.05)$. The use of processing methods reduced the population of salmonella and coliforms and increased the population of lactobacillus in the caecum. Most of the population of salmonella, lactobacillus, and coliforms of the caecum was observed in treatments of unprocessed, Bacillus Subtilis bacteria, and unprocessed, respectively (Table 4). The highest and lowest $\mathrm{pH}$ of caecum were related to unprocessed (6.82) and Aspergillus Oryzae fungi (6.21) treatments, respectively. 
Table 4 - Effect of treatments on microbial population of caecum $\left(\log _{10}\right.$ CFU/g).

\begin{tabular}{lcccc}
\hline Treatments & Salmonella & Lactobacillus & Coliforms & $\mathrm{pH}$ \\
\hline Unprocessed & $4.90^{\mathrm{a}}$ & $3.85^{\mathrm{b}}$ & $3.91^{\mathrm{a}}$ & $6.82^{\mathrm{a}}$ \\
$\begin{array}{l}\text { Processed by Lactobacillus } \\
\text { Plantarum (Bacteria) }\end{array}$ & $3.91^{\mathrm{b}}$ & $4.5^{\mathrm{a}}$ & $3.23^{\mathrm{b}}$ & $6.27^{\mathrm{b}}$ \\
$\begin{array}{l}\text { Processed by Bacillus } \\
\text { Subtilis (Bacteria) }\end{array}$ & $3.5^{\mathrm{b}}$ & $4.64^{\mathrm{a}}$ & $3.20^{\mathrm{b}}$ & $6.25^{\mathrm{b}}$ \\
$\begin{array}{l}\text { Processed by Aspergillus } \\
\text { Oryzae (Fungi) }\end{array}$ & $3.70^{\mathrm{b}}$ & $4.5^{\mathrm{a}}$ & $3.27^{\mathrm{b}}$ & $6.21^{\mathrm{b}}$ \\
$\begin{array}{l}\text { Processed by Neurospora } \\
\text { Sitophila (Fungi) }\end{array}$ & $3.76^{\mathrm{b}}$ & $4.63^{\mathrm{a}}$ & $3.29^{\mathrm{b}}$ & $6.24^{\mathrm{b}}$ \\
$\begin{array}{l}\text { Processed by Alcalase } \\
\text { enzyme }\end{array}$ & $3.81^{\mathrm{b}}$ & $4.49^{\mathrm{a}}$ & $3.32^{\mathrm{b}}$ & $6.25^{\mathrm{b}}$ \\
$\begin{array}{l}\text { SEM } \\
\text { Pvalue }\end{array}$ & 0.06 & 0.10 & 0.09 & 0.13 \\
\hline
\end{tabular}

SEM: Standard error of means. Means with different letters are significant $(p<0.05)$.

\section{Carcass traits}

The effects of canola meal process methods on carcass traits are presented in Table 5 . The effect of experimental treatment had significant effect on abdominal fat $(p<0.05)$. Processing methods of canola meal caused the reduction of abdominal fat. The highest decrease in abdominal fat was observed in the treatment that process with Aspergillus Oryzae fungi $(1.89 \%)$.

\section{DISCUSSION}

Canola contains anti-nutritional substances such as glucosinolate. Therefore, if canola is not processed before consumption, its nutritional value will be low and will have adverse effects on poultry health. In the present study, the processed canola by bacteria, fungi, and enzymes did not affect the egg traits of broiler breeder hens, which is in accordance with other reports (Goldberg et al., 2016; Zhu et al., 2019; Ziyad et al., 2019).

Canola processing improved fertility traits. But there was no difference between the methods used with bacteria, fungi, and enzymes. The processed canola has increased the palatability of the ration by reducing its antioxidants. On the other hand, phytate and available phosphorus have decreased and increased, respectively. Phosphorus has a positive effect on fertility traits. These results are consistent with other studies (Van Emous et al., 2015; AL-Dhanki et al., 2019; Ziyad et al., 2019).

In a study, the decreasing effect of enzymatic hydrolysis of canola with Alcalase was reported on the microbial population of broiler ceca (Karimzadeh et al., 2016b). In another study, the use of high levels of unprocessed canola had no effect on the microbial population of broiler ceca (Toghyani et al., 2017). These results are consistent with the results of the present study. In the present study, canola processing reduced the cecal pH. Subsequently, conditions for the growth of beneficial bacteria and the destruction of harmful microbes in the caecum were provided and the microbial balance of the gastrointestinal tract improved.

In a study, rapeseed meal was processed by Lactobacillus Acidophilus and Bacillus Subtilis, and Aspergillus Niger. It was reported that processed meal increased carcass traits weight and reduced abdominal fat (Ashayerizadeh et al., 2018). In another study, the use of high levels of unprocessed canola improved the carcass traits of broilers (Toghyani et al., 2017). These findings are consistent with the results of the present study. Canola processing improves the protein quality and fatty acid profile and improves bird performance.

Canola processing improved fertility hatchability, which caused an increase in the number of chickens. On the other hand, by reducing the population of harmful microbes and increasing the population of beneficial intestinal microbes, it improves the ability to absorb nutrients. All of the above is due to the reduction in the anti-nutritional substances of canola, which is caused by processing. Thus, canola processing improved its digestibility. In other words, protein quality and fatty acid profiles were improved. Therefore, the processed canola used by the bird improves its traits. It can be recommended to use the processed meal instead of the raw canola meal.

Table 5 - Effect of treatments on carcass traits (\%).

\begin{tabular}{|c|c|c|c|c|c|c|}
\hline Treatments & Breast & Thigh & Abdominal Fat & Spleen & Liver & Heart \\
\hline Unprocessed & 33.21 & 28.76 & $2.73^{a}$ & 0.14 & 2.85 & 0.82 \\
\hline Processed by Lactobacillus Plantarum (Bacteria) & 34.61 & 29.21 & $1.95^{b}$ & 0.14 & 2.80 & 0.85 \\
\hline Processed by Bacillus Subtilis (Bacteria) & 35.12 & 28.65 & $1.93^{b}$ & 0.13 & 2.79 & 0.85 \\
\hline Processed by Aspergillus Oryzae (Fungi) & 34.10 & 28.76 & $1.89^{b}$ & 0.14 & 2.78 & 0.87 \\
\hline Processed by Neurospora Sitophila (Fungi) & 35.31 & 29.12 & $1.94^{b}$ & 0.13 & 2.78 & 0.86 \\
\hline Processed by Alcalase enzyme & 33.19 & 29.93 & $1.96^{b}$ & 0.14 & 2.81 & 0.87 \\
\hline SEM & 1.13 & 1.09 & 0.06 & 0.03 & 0.05 & 0.04 \\
\hline$p$ value & 0.34 & 0.26 & 0.00 & 0.40 & 0.35 & 0.37 \\
\hline
\end{tabular}

SEM: Standard error of means. Means with different letters are significant $(p<0.05)$. 


\section{ACKNOWLEDGMENTS}

We are grateful to the Islamic Azad UniversityQaemshahr Branch, Iran for support.

\section{REFERENCES}

AL-Dhanki ZTM, AL-Jugifi WI, AL-Enzy AFM. Impact of feeding fermented wet feed on broiler breeder production performance and some hatchability traits. International Journal of Poultry Science 2019;18(3):116-121

Alkhalf A, Alhaj M, Al-homidan I. Influence of probiotic supplementation on blood parameters and growth performance in broiler chickens. Saudi Journal of Biology Science 2010;17:219-225.

Apata, D.F. Growth performance, nutrient digestibility and immune response of broiler chicks fed diets supplemented with a culture of Lactobacillus Bulgaricus. Journal of the Science Food and Agriculture 2008;88(7):1253-1258.

Araba M, Dale NM. Evaluation of $\mathrm{KOH}$ solubility as an indicator of over processing of soybean meal. Poultry Science 1990;69:76-83.

Ashayerizadeh A, Dastar D, Shams Shargh M, Sadeghi Mahoonak AR, Zerehdaran, Z. Effects of feeding fermented rapeseed meal on growth performance, gastrointestinal microßora population, blood metabolites, meat quality, and lipid metabolism in broiler chickens. Livestock Science 2018;216(4):183-190.

Bird AR, Croom WJ Jr, Fan YK, Daniel LR, Black BL, McBride BW, et al. Jejunal glucose absorption is enhanced by epidermal growth factor in mice. Journal of Nutrition 1994;124:231-240.

Brij PS, Shilpa V, Subrota H. Functional significance of bioactive peptides derived from soybean. Journal of Peptides 2014;20:16-22.

Chatila R, West AB. Hepatomegaly and abnormal liver tests due to glycogenosis in adults with diabetes. Medicine 1996;75(6):327-333.

Gibson GR, Roberfroid MB. Dietary modulation of human colonic microbiota:Introducing the concept of prebiotic. Journal of Nutrition 1995;125:1401-1412.

Goldberg EM, Ryland D, Aliani M, House JD. Interactions between canola meal and flaxseed oil in the diets of White Lohmann hens on fatty acid profile and sensory characteristics of table eggs. Poultry Science 2016;95(8):1805-1812.

Hu Y, Wang Y, Li A, Wang Z, Zhang X, Yun T, et al. Effects of fermented rapeseed meal on antioxidant functions, serum biochemical parameters and intestinal morphology in broilers. Food and Agricultural Immunology 2016;27(2):182-193.

Karimzadeh S, Seyfi M, Rezaei M. Effects of native probiotic (Dipro) on performance growth, digestive enzyme activities and intestinal morphology in broiler chickns. Proceedings of the 5th International Veterinary Poultry Congress; 2016; 31 Jan 1 Feb; Tehran, Iran; 2016. p. 228.
Kermanshahi $\mathrm{H}$, Abbasi Pour AR. Replacement value of soybean meal with rapseed meal supplemented with or without a dietary NSP-degrading enzyme on performance, carcass traits and thyroid hormones of broiler chickens. International Journal of Poultry Science 2006;5:925-930.

Khalil A. Nutritional improvement of an Egyptian breed of mung bean by probiotic lactobacilli. African Journal of Biotechnology 2006;5(2):206212.

McNeill L, Bernard K, MacLeod MG. Food intake, growth rate, food conversion and food choice in broilers fed on diets high in rapeseed meal and pea meal, with observations on sensory evaluation of the resulting poultry meat. British Poultry Science 2004;45:519-523.

Pasupuleti VK, Demain AL. Protein hydrolysates in biotechnology. New York: Springer; 2010.

Ravindra AP. Value-added food: single cell protein. Biotechnology Advances 2000;18:459-479

Recoules E, Lessire M, Labas V, Duclos MJ, Combes-Soia L, Lardic L, et al. Digestion dynamics in broilers fed rapeseed meal. Scientific Reports 2019;9:3052- 3063

Singhania RR, Patel AK, Soccol CR, Pandey A. Recent advances in solidstate fermentation. Biochemical Engineering Journal 2009;44:13-18.

Toghyani M, Girish CK, Wu SB, lji PA, Swick RA. Effect of elevated dietary amino acid levels in high canola meal diets on productive traits and cecal microbiota population of broiler chickens in a pair-feeding study. Poultry Science 2017;96(5):1268-1279.

Tripathi MK and Mishra AS. Glucosinolates in animal nutrition: a review. Animal Feed Science and Technology 2007;132:1-27.

Van Emous RA, Kwakkel RP, Van Krimpen MM, Van den Brand $\mathrm{H}$, Hendriks $\mathrm{WH}$. Effects of growth patterns and dietary protein levels during rearing of broiler breeders on fertility, hatchability, embryonic mortality, and offspring performance. Poultry Science 2015;94(4):681-691.

Zeb A. Possibilities and limitations of feeding rapeseed meal to broiler chicks [thesis PhD]. Gottingen (DE): University Gottingen; 1998.

Ziyad TM AL-Dhanki, AL-Jugifi WI, AL-Enzy AFM. Impact of feeding fermented wet feed on broiler breeder production performance and some hatchability traits. International Journal of Poultry Science 2019;18(3):116-121.

Zhu LP, Wang JP, Ding XM, Bai SP, Zeng QF, Su ZW, et al. The effects of varieties and levels of rapeseed expeller cake on egg production performance, egg quality, nutrient digestibility, and duodenum morphology in laying hens. Poultry Science 2019;98(10):4942-4953. 
